\title{
THE CURRENT SITUATION RELATED TO THE PUBLIC-PRIVATE PARTNERSHIP IN TURKEY
}

\author{
Recep Emre ERiçOK ${ }^{1}$
}

\begin{abstract}
This study aims to be able to reveal the current situation related to the Public-Private Partnership in Turkey. In the study, the current status of the Public-Private Partnership in theory, literature and legislation will be determined and statistical results will be included. Within the scope of the study, the chnage in the Public Finance Approach, the effects of this approach on the Public Enterprise methods and the developments in the Public-Private Partnership will be examined. In Turkey, studies including the legislative development of the Public-Private Partnership and its recent costs and pricing features are carried out to enable the Public Expenditure Administration. As a result of these studies, it is necessary to state the evaluation and the recommendations of the Public-Private Partnership. In the Public-Private Partnership which has been tried to establish the legal infrastructure by making various legal regulations since 1980's, the increase in the number and the variety of laws and regulations related to the PPP, has caused the complexity of the legislation and the lack of a certain standard in the applications. In addition to this, cost and pricing problems, which are frequently on the agenda, are emerging. For the elimination of the legislation's complexity and for the need of efficiency, effectiveness and economy approaches in the Public Expenditure Administration, the need to establish a Framework Law related to the PPP as it has been explained in many Public Policy documents. In the study, there is a result that it has been necessary to make adequate and up-to-date legal regulations, in the context of international and Turkey.
\end{abstract}

Keywords: The Public-Private Partnership, The Public Expenditure Administration, The Public Benefit, The Legislation, The Cost, The Pricing.

JEL Code: H0O, H6O.

\section{Introduction}

In Turkey, the models such as Concession, Build-Operate and Transfer (BOT), Transfer of Operating Rights (TOR), Build and Operate (BO), Build-Lease and Transfer (BLT) are applied, at public services and public investments, related to the Public-Private Partnership (PPP). In this context, various legal regulations have been made since 1980s and the legal infrastructure of the PPP methods has been tried to be established. With these legal regulations, the increase in the number and the variety of laws and regulations related to the PPP, has caused the complexity of the legislation and the lack of a certain standard in the applications. This situation reveals the results that it has been necessary to make adequate and up-to-date legal regulations, in the context of international and Turkey and therefore it has been necessary to establish a Framework Law related to the PPP, as it has been explained in many Public Policy documents (T.C. Kalkınma Bakanlığı, 2015: i).

\footnotetext{
1 Assist. Prof., İstanbul University, reericok@istanbul.edu.tr
} 
In addition, there is a need for some solutions to the problems related to the cost and the pricing in the Public-Private Partnership. For example, according to the Public Expenditure Administration, if there is a price guarantee preference in the contracts signed with the private sector companies, if the exchange rates increase, the prices in Turkish Lira increase over the payment plan. This situation causes the public loss. For this reason, comprehensive budget estimates and projections on the cost and the pricing should be taken into account in the signed contracts.

\section{The Change in the Public Finance Approach and the Development of the Public-Private Partnership}

Some of the developments that caused the change in the Public Finance Approach are that the borderlines between the public sector and the private sector are becoming porous and that the PPP increases. Nowadays, the PPP and competition beyond borders stand out in meeting global challenges (Kaul \& Conceição, 2006: 4).

For this reason, the partnership between the public sector and the private sector and the countries and the global markets becomes important in solving problems. Therefore, while the importance of the international partnerships increases, the PPP also stands out.

Nowadays, especially as a result of the increase in the need for infrastructure investments, the difficulty of the public institutions to realize public investments with their own resources raises the search for resources and methods. The PPP is a project finance method (Şirin, 2018: 27-28).

The PPP is a mechanism to procure and implement public infrastructure and/or services using the resources and expertise of the private sector. The PPP combine the skills and resources of both the public and private sectors through sharing of risks and responsibilities. This situation enables the public sector to benefit from the expertise of the private sector, and allows the public sector to focus instead on policy, planning and regulation. In order to achieve a successful PPP, a careful analysis of the long-term development objectives and risk allocation is essential. The legal and institutional framework in the country also needs to support the PPP and provide effective governance and monitoring mechanisms for the PPP (The World Bank, 2016).

The main objective of the PPP is to increase the expertise of the public sector to identify, negotiate, manage and implement successful PPP projects. This situation is done through exchange of knowledge and experiences of the PPP by countries, including experts from public and private sectors, particularly in the identification and testing of best application. The activities will result in standards, guides on best application, studies and innovative tools that can be used in capacity-building programmes and training (UNECE, 2019).

\section{The Legislation and the Public Policy Documents Related to the Public-Private Partnership in Turkey}

The Legislation and Public Policy documents related to the PPP in Turkey are examined under two separate titles. 


\subsection{The Legislation Related to the Public-Private Partnership in Turkey}

The legislation related to the PPP in Turkey is examined under two titles as the 1982 Constitution of Turkey and the Legislation related to the PPP Models.

In this context, according to Article 47 titled Nationalization and Privatization of the 1982 Constitution of Turkey, it is expressed that the private enterprises which realize services in the qualification of the public service can be nationalized in where the public benefit requires it, that the nationalization is realized with its real value, that the method and procedures for calculating the real value are regulated by the law. In addition, it is expressed that it is regulated by the law that the principles and the procedures related to the privatization of the enterprises and the assets owned by the state, the public economic enterprises and the other public legal entities. Furthermore, it is expressed that it is regulated by the law that which of the investments and the services carried out by the state and the public economic enterprises and the other public legal entities may be produced by private or legal entities or may be transferred to them (T.C. 1982 Anayasası).

Furthermore, there is many laws related to the PPP models such as Build-Operate and Transfer (BOT-Laws Numbered 3996, 3096 and 3465), Build-Lease and Transfer (BLT-Law Numbered 6428, Article 20 of Law Numbered 351), Build and Operate (BO-Law Numbered 4283), Privatization and Transfer of Operating Rights (TOR-Law Numbered 4046, Article 33 of Law Numbered 5335, Article 218/A of Law Numbered 4458) and Concession (Laws Numbered 4483, 4501 and 406 (T.C. Kalkınma Bakanlığı, 2018: 23).

\subsection{The Public Policy Documents Related to the Public-Private Partnership in Turkey}

The Public Policy documents related to the PPP in Turkey are expressed as The Tenth Development Plan: 2014-2018, The Investment Program Preparation Guide of 2019, The New Economic Program (NEP) Equilibration-Discipline-Change 2019-2021: The Medium Term Program.

In The Tenth Development Plan: 2014-2018, it is explained that (T.C. Kalkınma Bakanlığı, 2013);

- in addition to public resources, legal regulations have been made for the realization of health investments by the PPP method (in Article 168 titled Health),

- alternative finance and operating models, especially the PPP, will be implemented in the construction and operation of sports facilities (in Article 340 titled Policies),

- in meeting of Turkey's growing infrastructure needs, the use of alternative finance models with the participation of the private sector is required as well as the use of public resources, furthermore, the need for the development of the institutional capacity of the public institutions based on expertise in the project planning and administration processes related to the PPP is important (in Articles 581 and 582 titled Public Investments),

- in public investments, it will be given priority to education, health, drinking water and sewage, science-technology, transportation and irrigation sectors, including projects related to the PPP (in Article 589 titled Public Investments),

- a strategy document related to the PPP will be prepared and the PPP legislation will be established in the form of a Framework Law (in Article 594 titled Public Investments), 
- the coordination of policies and the applications related to the PPP will be strengthened and an effective monitoring and evaluation system that will measure the risks and impacts of projects on the budget will be established (in Article 595 titled Public Investments),

- it will be ensured that local technical consultancy companies will operate more effectively in all production processes of construction sector and in areas such as the PPP projects and urban transformation (in Article 886 titled Construction, Engineering-Architecture, Technical Consultancy and Contracting Services).

In The Investment Program Preparation Guide of 2019 and under the title Priorities of Public Investment Policy For 2019-2021 Period, it is explained that (TCCSBB, 2018a);

- public infrastructure investments will be planned and carried out in the form of to support the reduction of the production costs in the private sector, the formation of new production capacities and thus the innovative and competitive development of the production, it will be given priority to the use of domestic goods in public investments, including projects related to the PPP (in Article 10 titled General Priorities),

- it will be taken care to the use of the PPP, especially in critical and major public infrastructure projects requiring advanced technology or high financial resources, taking into account the cost effectiveness (in Article 11 titled General Priorities),

- it will be given priority to education, health, drinking water and sewage, science-technology, transportation, energy and irrigation sectors, including projects related to the PPP in public investment allocations for 2019-2021 Period (in Article 15 titled Sectoral Priorities),

In The New Economic Program (NEP) Equilibration-Discipline-Change 2019-2021: The Medium Term Program, it is explained that it is aimed to establish a framework for more effective and financially efficient PPP applications and to ensure these applications being integrated in this context (TCHMB, 2018).

\section{The Applications Related to the Public-Private Partnership in Turkey}

As in the world, also in Turkey since the 1980's, the number of the PPP, which is applied primarily in infrastructure then in the health sector, is increasing in various sectors related to the public sector projects. The analysis of the distribution of the PPP by sectors and models will make an important contribution to examine the diversity and alternatives of the PPP in the Public Expenditure Administration applications.

When the distribution by sectors of the PPP in Turkey is examined, it is seen that the PPP has been first in the distribution by sectors, as project number, with 89 projects in the energy sector, has been second with 42 projects in the road sector and has been third with 22 projects in the port sector. When the distribution by models of the PPP in Turkey is examined, it is seen that BOT has been first in the distribution by models, as project number, with 108 projects, TOR has been second with 104 projects and BLT has been third with 21 projects (TCCSBB, 2018b).

When the contribution of the PPP in public projects is considered, the importance of the legislation change and the renewal of the contracts in terms of cost and pricing is seen. 
The PPP is generally used in both developed and emerging countries. At the United Nations Conference on Trade and Development (UNCTAD), the importance of the realization and meeting of the Sustainable Development Goals by partnerships was stated by determining the 17th Development Goal as "Partnerships for the Goals". The PPP has been also generally considered as a part of this Goal. In this context, it is understood that the PPP will be used more widely in underdeveloped and emerging countries for the funds it will provide in addition to public investments and for the efficiency and effectiveness it will provide. The findings, evaluations and recommendations related to the PPP in Turkey, which is applied since the 1980's and seen increase in its applications since the 2000's, are stated as follows (T.C. Kalkınma Bakanlığı, 2018: 56-57):

- in the next years, the PPP is expected to be used more widely in the transport and health sectors as well as in the small scale projects related to the urban infrastructure (for example such as solid waste, waste water),

- the current PPP legislation needs to be reregulated in a form of ensure the application of different models in different sectors and to respond to needs,

- the need for the project is increasing both in the world and in Turkey. The competition of the private sector for finance sources related to the projects is increasing. This situation increases the importance of the project prioritization which enables finance resources to be used in the strategic projects,

- the most important elements of a successful PPP project are stated as the effective procurement process, the effective administration of the risk sharing and transfer, the effective determination of outputs and expectations, the affordability, the return on expenditure and the effective contract administration and payment mechanism. A thorough and rigorous project preparation is required for the effective application of all these elements. In this context, the economic benefits of the projects, the obligations they will bring and their possible risks will be determined and thus, an efficient procurement and contract administration process will be ensured with the minimazation of the uncertainties. An effective monitoring and evaluation process will make an important contribution to the improvement of the PPP as well as the success of the project,

- it will be beneficial to create application manuals on the PPP, to increase the capacities of the institutions in the application process, to evaluate alternative finance methods in case of financial difficulties, and to complete the technical and legal infrastructure for this purpose.

\section{Conclusion}

When the results obtained within the scope of the study are examined; nowadays, as in the world, also in Turkey, important processes have been carried in the PPP in the context of the Public Expenditure Administration applications. New methods and suggestions to be produced by taking into account the principles of efficiency, effectiveness and economy in the Public Expenditure Administration and providing the public benefit can make important contributions in this field. The new legislation studies on the PPP and the measures about the cost and the pricing will also make important contributions to prevent the public loss. Therefore, in order to establish effective public policies, a comprehensive budget estimate and projection on the cost and the pricing is required in the contracts related to the Public Expenditure Administration 
applications. Thus, as in the budget preferences and priorities, the PPP can be effectively applied by integrated legislation and the contracts effectively prepared, also in the Public Expenditure Administration applications. Consequently, the public choices will also contribute to the formation of rational and effective results in the public policies.

\section{References}

Kaul, Inge \& Conceição, Pedro (2006). "Why Revisit Public Finance Today? What This Book Is About", The New Public Finance: Responding to Global Challenges, (Ed.) Kaul, Inge and Conceição, Pedro, New York Oxford, Oxford University Press, pp. 3-27.

Şirin, Z. Ertunç (2018). “Türkiye'de Kamu Özel Ortaklığı Yönteminin Hukukî Altyapısı”, Maliye Araştırma Merkezi Konferansları, Altmışbirinci Seri-Yıl 2017 (1), Yayın No: 105, İstanbul, 2018, ss. 25-58.

T.C. 1982 Anayasası.

T.C. Kalkınma Bakanlığı. (2013). Onuncu Kalkınma Planı: 2014-2018, Temmuz 2013, Ankara.

T.C. Kalkınma Bakanlığı. (2015). Kamu Özel İşbirliği Mevzuat, Yatırım Programlama İzleme ve Değerlendirme Genel Müdürlüğü, Mayıs 2015, Ankara.

T.C. Kalkınma Bakanlığı. (2018). Kamu-Özel İşbirliği Raporu 2017: Dünyada ve Türkiye'de KamuÖzel Işsbirliği Uygulamalarına ilişkin Gelişmeler Raporu 2017, Yayın No: 2983, Yatırım Programlama İzleme ve Değerlendirme Genel Müdürlüğü, Mayıs 2018, Ankara.

TCCSBB (T.C. Cumhurbaşkanlığı Strateji ve Bütçe Başkanlığı) (2018a) 2019 Yılı Yatırım Programı Hazırlama Rehberi, 10 Ekim 2018, Ankara.

TCCSBB (T.C. Cumhurbaşkanlığı Strateji ve Bütçe Başkanlığı) (2018b) Kamu Özel Ortaklığı Proje Göstergeleri, Ankara.

TCHMB (T.C. Hazine ve Maliye Bakanlığı). (2018). Yeni Ekonomi Programı (YEP) DengelenmeDisiplin-Değişim 2019-2021: Orta Vadeli Program, Eylül 2018, Ankara.

The World Bank. (2016). "About Public-Private Partnerships", 18.08.2016, https://ppp.worldbank. org/public-private-partnership/about-public-private-partnerships, (27.02.2019).

UNECE (The United Nations Economic Commission for Europe-Birleşmiş Milletler Avrupa Ekonomik Komisyonu). (2019). "Public-Private Partnerships (PPP)", http://www.unece. org/ceci/ppp.html, (27.02.2019). 